Тетяна ЧУРПІТА

\title{
МИКОЛА ТРЕГУБОВ: ШЛЯХ ДО ГУЛАГУ І ТАБІРНА ТВОРЧІСТЬ
}

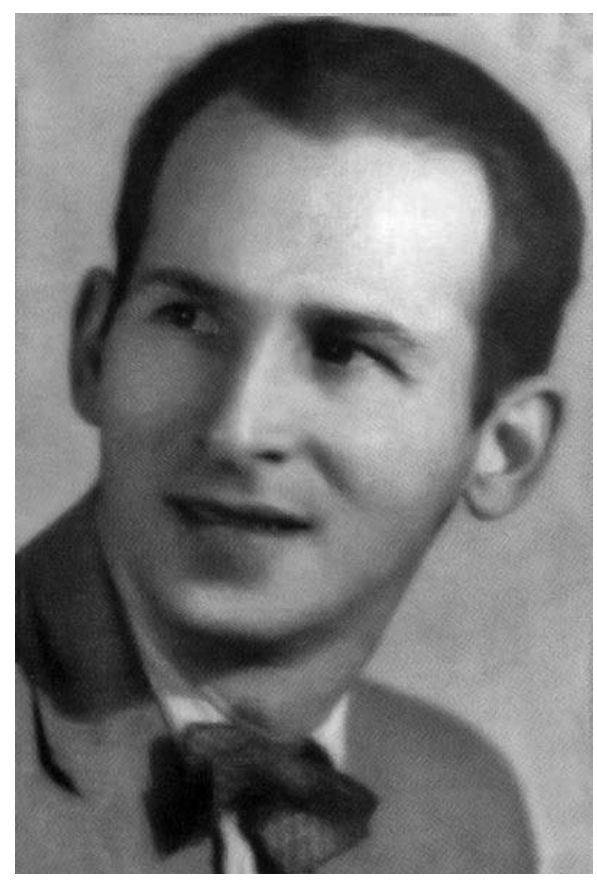

У статті розглянуто причини й передумови ув 'язнення заслуженого артиста УРСР М. Трегубова, відтворюються маловідомі факти його сиенічного життя за часів Другої світової війни. Основну увагу приділено особливостям перебування артиста у виправно-трудовому таборі системи ГУЛАГ, його виконавській та балетмейстерській діяльності в Центральному театральному ансамблі Волгобуду.

Ключові слова: Львівський оперний театр, ГУЛАГ, репресії, театр, балетмейстер, соліст балету, творча діяльність.

В статье рассмотрены причины и предпосылки заключения заслуженного артиста УССР М.Трегубова, воспроизводятся малоизвестные факты его сиенической жизни во времена Второй мировой войны. Основное внимание уделено особенностям пребывания артиста в исправительно-трудовом лагере системы ГУЛАГ, его исполнительской и балетмейстерской деятельности в Центральном театральном ансамбле Волгостроя.

Ключевые слова: Львовский оперный театр, ГУЛАГ, репрессии, театр, балетмейстер, солист балета, творческая деятельность.

The article considers the reasons and premises of imprisonment of Honored Artist of the USSR M. Trehubov and shows little known facts of his scenic life during the German-Soviet War. The main attention is paid to the peculiarities of the artist's residence in a labour camp of the Gulag system, his choreographic and performing activity in the Central theatrical ensemble of Volhobud.

Keywords: Lviv Opera Theatre, GULAG, repression, theatre, ballet master, ballet soloist, creative activity.

У 2014 році Україна вкотре зіткнулася зі своїм північним сусідом у кривавій боротьбі за незалежність. Російська Федерація, яка є прямим правонаступником тоталітарного СРСР, відновила страшну людиноненависницьку традицію - відправляти в тюремні камери опонентів злочинного режиму. У російських застінках і тюрмах опинилися приблизно 50 українських патріотів, серед яких — прості громадяни, політичні активісти та діячі мистецтва (режисер Олег Сенцов).

Оскільки частина української території окупована, а маховик переслідувань запущений знову, вкрай корисно знати досвід відомих діячів української культури, які за часів сталінського диктату були безпідставно звинувачені радянським «правосуддям» у зраді батьківщини, але, незважаючи на це, продовжували нести світло своєї творчості навіть у похмурому ГУЛАзі.

До таких особистостей належить відомий хореограф, заслужений артист УРСР, заслужений діяч мистецтв, автор численних балетних вистав, хореографічних номерів і лібрето, балетмейстер, педагог Микола Івнович Трегубов (1912-1997). Він працював солістом балету, головним балетмейстером, драматичним актором у театрах опери i балету у багатьох містах тодішнього Радянського Союзу (Ленінград, Київ, Львів, Донецьк, Одеса, П'ятигорськ, Челябінськ), за кордоном (Польща, 
НДР), але переважну більшість свого творчого життя провів на теренах України.

У його виконавському доробку понад двадцять дві балетні партії, а перелік назв балетів, опер, оперет, поставлених М. Трегубовим становить понад 52 найменування. Він $\epsilon$ автором лібрето балетів «Пер Гюнт» (1956), «Чорне золото» (разом $з$ П. Вірським, А. Лукацьким) (1960), «Дюймовочка» (разом з Л. Трофімовою) (1964), «Великий вальс» (1955), «Урок життя» (1963) тощо.

За роки балетмейстерської діяльності М. Трегубов виховав цілу плеяду артистів балету, які отримали почесні звання, серед них: народна артистка УРСР Н.Слободян, заслужені артисти УРСР О. Сталінський, М. Мономахов, В. Ільїнська та О. Поспєлов.

М. Трегубов пройшов творчими шляхами крізь буремні тяготи війни як танцівник і балетмейстер, працюючи в різних художніх колективах. Але плідна робота на професійній ниві не вберегла майстра від п'яти років таборів.

Попри важливість для розуміння вкладу діяча в національний культурологічний процес і розвиток балетного мистецтва в Україні, основні відомості, що стосуються діяльності М. Трегубова за часів Другої світової війни та в період ув'язнення, були викреслені з творчої біографії митця. За радянських часів науковці уникали незручних тем і торкалися лише дозволених періодів у житті майстра, тобто подій другої половини XX століття.

Хронологія життя і творчості хореографа, що представлена в довідниках і енциклопедії «Балет», у працях: В. Туркевича [30], Є. Суриц [27], потребує доповнень та уточнень. Згадки про діяльність М. Трегубова знаходимо в спогадах акторів діаспори, які працювали у Львівському оперному театрі (ЛОТі) у період 1941-1944 pp. (Нью-Йорк-Париж-Сідней-Торонто, 1975, 1992), у працях О. Паламарчук [20], В. Гайдабури [7], С. Максименко [13; 14].

Останнім часом з'являються поодинокі публікації, присвячені творчості балетмейстера в роки збройного протистояння фашистської Німеччини i СРСР (Н. Миронюк [15; 16]), але вони лише частково окреслюють творчий доробок М. Трегубова в ЛОТi, не розкривають повною мірою передумов його ув'язнення.

Завдяки відкритому доступу до архівів за роки державної незалежності України дедалі частіше стали з'являтися матеріали, котрі свідчать про діяльність комуністичної карально-репресивної державної машини під назвою Головне управління таборів Радянського Союзу, розкривають величезну криваву пляму історії народів СРСР. Та, на жаль, серед численних публікацій про репресованих діячів культури й мистецтва, хореографам, артистам балету приділено найменше уваги.

На цьому тлі вирізняється книга доктора мистецтвознавства В. Гайдабури «ГУЛАГ і світло театру: Листи із зони Сергія та Анни Радлових (1946-1953)» (Київ, 2009). У ній є інформація про перебування М. Трегубова в табірному театральному ансамблі, яким керував відомий режисер С. Радлов. В опублікованих листах віднайдено безцінні відомості про умови життя і творчість артистів за колючим дротом.

У контексті історії сталінських репресій дослідження Е. Епплбом [9] доповнює уявлення про пережиті біль і страждання, мільйонні людські жертви і скалічені долі, повертаючи українцям втрачену пам'ять про систему концентраційних трудових таборів, яка була небаченим за своїми масштабами й жорстокістю інструментом експлуатації, гноблення і винищення комуністичною владаю народів Радянського Союзу.

Мета статті - спираючись на матеріали досліджень про історію ГУЛАГу, автобіографічні дані і спогади колег М. Трегубова про перебування майстра за колючим дротом, відтворити події, які передували ув'язненню, умови життя і творчості хореографа в табірному театральному ансамблі.

Микола Іванович Трегубов народився 25 березня 1912 р. в м. Ставрополі, у багатодітній родині робітника Івана Олександровича Трегубова та домогосподарки Катерини Петрівни Трегубової. Після закінчення в 1928 році трудової середньої школи №1 Відділ народної освіти направив Миколу Трегубова навчатись у Ленінградське хореографічне училище, де юнак освоював мистецтво танцю під керівництвом найкращих викладачів В. Пономарьова і В. Семенова.

Отримавши у 1935 р. класичну хореографічну освіту, М. Трегубов працював два роки артистом балету в Ленінградському державному академічному театрі опери й балету ім. С. М. Кірова. У 1937 році Комітет у справах мистецтв направив М. Трегубова до Київського академічного театру опери і балету, де він до 1940 р. обіймав посади соліста балету та асистента балетмейстера.

У 1940 році, за дорученням Київського Комітету в справах мистецтв України, артиста було спрямовано на розбудову Львівського державного театру опери та балету, де він водночас керував балетною трупою, виконував провідні партії та здійснював окремі постановки в оперних виставах. 
Звичний життєвий ритм М. Трегубова, як і багатьох мільйонів людей, кардинально змінився в червні 1941 р., коли нацистська Німеччина напала на Радянський Союз. У 1941 році, коли німці стрімко наступали, М. Трегубов евакуювався зі Львова до Києва, а потім приїхав на Кавказ, у П'ятигорськ, де працював балетмейстером у Театрі музичної комедії. У 1942 р. поїхав до рідного Ставрополя й потрапив в окупацію. Вісімнадцять місяців М. Трегубову вдавалося уникати арешту. Але 13 грудня 1942 р. він став «дорогоцінним трофеєм» ворога, який повернув його до Львівського оперного театру (ЛОТ). Рік і сім місяців майстер працював у театрі балетмейстером та прем'єром балету [1].

В особі М. Трегубова - етнічного росіянина за походженням - балетний сектор ЛОТу отримав професійного класичного танцівника, балетмейстера-постановника та педагога-наставника молодих артистів балету. За час роботи в театрі (приблизно 18 місяців) він написав лібрето і здійснив постановку балету «Серпанок П'єретти» на музику угорського композитора Е. Донаньї та інших композиторів в обробці Л. Туркевича [25], окремі номери в операх «Кавалерія Рустікана» П. Масканьї [14], «Продана наречена» Б. Сметани [23], «Ноктюрн» М. Лисенка [2], «Маргарета» («Фауст») Ш. Гуно [31] і в опереті «Пташник із Тиролю» К. Целлера [5], готував збірні концертні програми («Сорокатий вечір»), брав участь у мистецьких заходах [10].

Балетна трупа ЛОТу отримувала позитивні відгуки в пресі як колектив професіоналів «справжньої європейської величини, очолюваний такими талановитими режисерами, як Вігілєв, Штенгель чи Трегубов» [24].

Виконавський талант останнього розкрився в партіях іскрометного Базиля в «Дон-Кіхоті» [3], Фреда (Арлекін) у «Серпанку П’єретти» [25], Пер Гюнта в однойменному балеті [18], у сценах одноактівки «Вальпургієва ніч» 3 опери «Маргарета» («Фауст») [31]. Створюючи образи персонажів, М. Трегубов знаходив несподівані акторські рішення, що акцентували індивідуальність їхніх характерів.

Газета «Краківські вісті» неодноразово високо оцінювала роботу М. Трегубова-виконавця, зазначивши, що він - «танцюрист високої кляси, здібний творити вищі танкові форми і вийти далеко над рівень пересічних танкових продукцій» [21]. Доктор Йосип Хоминський на сторінках газети «Львівські вісті» зауважив: «В поодиноких частинах „Вальпургієвої ночі”, технічна справ- ність деяких учасників сягала до найвищих меж досконалості. Найкращими з них були прима-балерина В.Переяславець і З. Сугробкіна та сам М. Трегубів» [31].

Силами М. Трегубова і його колег балетний сектор театру перетворився в самостійну творчу одиницю, здатну створювати якісні вистави європейського зразка, незважаючи на те, що традиції балетного театру в Галичині були зовсім молодими.

Уже в 1944 році склад танцюристів збільшився до 64 осіб [11, 338], з них 43 - солісти різного рангу $[7,288]$. Завдяки цьому можливості балетної трупи значно розширилися. Від вистави до вистави виконавська майстерність артистів балету удосконалювалась, про що неодноразово писали театральні оглядачі. Це відбувалося й завдяки роботі М. Трегубова 3 молодими виконавцями, які вливались у колектив. Паралельно, за повного навантаження прем'єра балету й балетмейстера, М.Трегубов працював 3 артистами в репетиційному залі як педагог і балетмейстер-репетитор, готуючи 3 ними нові партії. Цей факт не можна назвати звичайним, адже далеко не всім визнаним солістам вдається передавати учням свою майстерність. «Як танцюрист, захоплює нас щораз наново кожним своїм виступом; як балетмейстер, виховав він нові таланти, що саме підготовлюються до вечірнього виступу», - зазначали «Львівські вісті» про «подвійне» життя майстра [4].

Зважаючи на ідеологічну ситуацію в регіоні, колектив театру не міг не брати участь у гуманітарних та громадських ініціативах окупаційного режиму. Підсумком однієї з подібних акцій, яку Трегубов разом із 16 членами трупи провели на Різдво 1943 р., стала зібрана сума обсягом 27730 злотих на подарунки постраждалим бійцям [28; 8].

За час роботи у Львові балетмейстер співпрацював зі своїми колегами, колишніми акторами ЛОТу, які очолили українські театри в інших містах регіону. Наслідком спільної роботи була національно-патріотична вистава «Шаріка» в Українському театрі ім. Івана Франка в Станіславові, танцювальні частини якої були втілені завдяки талантові балетмейстера і виконавця М. Трегубова [19].

Хореограф разом із побратимами по цеху намагався донести до глядача образи і зразки світової балетної класики, формуючи тим самим його високі театральні смаки. Для українців балетний сектор Львівської опери став центром духовної культури, самоідентифікації, важливим освітнім 
осередком, творчою лабораторією 3 підготовки професійних кадрів для українських театрів.

Статистика роботи ЛОТу в період липня 1941 - січня 1944 pр. вражає й сьогодні: 750 вистав 3 усіх ділянок театрального мистецтва за два 3 половиною роки праці, які побачили понад 600 тис. глядачів. 3 них -350 тис. українців, 250 тис. німців та їхніх союзників [26]. Для порівняння: за 2015 р. фактична кількість глядачів на ранкових та вечірніх виставах у Львіському національному академічному театрі опери та балету імені Соломії Крушельницької становила 91, 9 тис. осіб [12].

Така відвідуваність свідчить про пріоритети національних, культурних цінностей у середовищі тодішнього українства, що відображалося і в кількості «зіграних» постановок, у підготовці яких чільну участь брав М. Трегубов. Наприклад, оперета «Пташник із Тиролю» К. Целлера пройшла 29 разів, вкрай вдала для ЛОТу вистава «Серпанок П'єретти» за неповний сезон - peкордні 33 рази [20, 38], але опера «Маргарета» («Фауст») дивувала публіку ще довше - протягом 34 вечорів [11, 330].

Та доленосні історичні події внесли свої корективи в роботу колективу: налагоджений титанічними зусиллями митців розвиток Львівської опери перервався приходом у місто радянських військ 27 липня 1944 р. Ті артисти, які працювали у 1941-1944 pp. «для німців», емігрували й опинилися на Заході, інші, також не зі своєї волі, на Сході. До місцевого населення радянське керівництво ставилося 3 пересторогою, тож жителі та артисти театру, які не покинули місто, були змушені перелаштовуватися на новий лад під пильним оком радянських спецслужб. Поступово на «нові рейки» переходила і Львівська опера, у якій розпочалася енергійна робота над створенням нового колективу, основною вимогою до якого були «радянська позиція» й дух соціалістичного реалізму.

У столиці Галичини була одразу оголошена мобілізація. 3 огляду на це, у вересні 1944 р. М. Трегубова призвали в Червону Армію, балетмейстером у військовий Ансамбль Першого Українського фронту, яким керувала Л. Чернишова. 3 1944-го до 1945 рр. артист перебував у складі колективу на території Польщі $[1 ; 17,156]$. Ансамбль дав 2126 концертів за сорок місяців війни. 3 частинами Червоної Армії він пройшов бойовий шлях у 3500 кілометрів від Кавказу до Вісли. Чехи і словаки, угорці, румуни, поляки захоплено сприймали вокально-хореографічне мистецтво ансамблю 3 України [22]. Восени 1945 р. Ансамбль пісні і тан- цю УРСР після тривалої і плідної творчої діяльності в Центральній групі військ був відкликаний до столиці України, де фронтову творчість колективу високо оцінила громадськість.

Попри плідну роботу артиста в прифронтових зонах, навіть через рік і три місяці Радянська влада не забула про діяльність М. Трегубова в ЛОТі за часів німецької окупації. Незважаючи на те, що митець не мав ніяких особистих симпатій до окупаційної влади, а в його постановках не було жодного політичного чи ідеологічного підтексту, творчий доробок М. Трегубова був розцінений як робота на ворога, тож 1 грудня 1945 р. артиста арештовують і засуджують на п'ять років таборів - досить м'який вирок для тих часів. Відповідно до цього М. Трегубов ще мав шанси вийти на волю й розпочати нове життя [29].

Хореографа відправили відбувати покарання на Волгобуд, Волзький виправно-трудовий табір (BTT) МВC СРСР, підпорядкований Головному управлінню таборів промислового будівництва. Його було організовано в лютому 1944 р. в результаті об'єднання Управління будівництва гідротехнічних вузлів на річці Волга і Рибінського ВТТ. Пізніше, у квітні 1946 р. Волгобуд був виділений у самостійний табір із підпорядкуванням ГУЛАГу та присвоєнням найменування «Волзький ВТТ МВС». Табір розташовувався в селі Перебори Рибінського району Ярославської області.

Окрім обслуговування роботи Волгобуду, закінчення будівництва гідровузлів в Угличі та Щербакові (Рибінську), в'язні виконували контрагентні роботи (у тому числі на Рибінському механічному заводі №1 Головпромбуду), займалися лісозаготівлею, видобутком каміння, швацьким виробництвом, випуском товарів широкого споживання, сільськогосподарськими роботами, виловом і переробкою риби. Чисельність в'язнів станом на 01.04.46 дорівнювала 17338 чол. (01.01.47 - 21379 чол.; $01.01 .48-18440$ чол.; 01.01 .50 - 17399 чол.) $[6,43]$.

На тлі відомих нам сьогодні гулагівських жахів умови перебування М. Трегубова в таборі можуть здатися менш жорстокими. Він не тягав вручну каміння, не будував дороги, не працював на лісоповалі, робочий день його не сягав 11-12 годин, як у більшості засуджених [9, 165-166]. В. Гайдабура, оцінюючи табірні порядки, зауважив, що «це місце від його заснування призначалося для ув'язнених з різною категорією інвалідності і мало відповідну лікувальну базу» $[6,38]$.

При таборі функціонував культурно-виховний відділ (КВВ), якому підпорядковувався Цен- 
тральний театральний ансамбль. Сюди «пощастило» потрапити і М. Трегубову. Культурно-виховний відділ, який був своєрідною віддушиною для ув'язнених, мав у своєму розпорядженні й бібліотеку. Крім того, артисти за колючим дротом мали можливість отримувати книги 3 волі й листуватися.

Табірний колектив очолював відомий радянський режисер і педагог, заслужений артист РРФ$\mathrm{CP}$, заслужений діяч мистецтв РРФСР, орденоносець, один із найбільш освічених і талановитих творців мололодого радянського театру - Cергій Ернестович Радлов (1892-1958). Випускник факультету класичної філології Петербурзького університету, учень В. Мейєрхольда, якого по-звірячому катували, а в лютому 1940 р. розстріляли в катівнях НКВС. На сцені ленінградської Ак-драми (кол. Александринський театр) митець ставив класиків (Аристофан, Шекспір) і сучасників (Толлер, Замятін). В Ак-опері (кол. Маріїнський театр) здійснив постановки «Бориса Годунова» за авторською партитурою, «Любов до трьох апельсинів» С. Прокоф'єва, опери Ф. Шрекера, А. Берга. Радлова згадано як постановника на афішах балетів Б. Асаф'єва «Полум'я Парижа» та «Бахчисарайський фонтан». Йому належав сценарій балету С. Прокоф'єва «Ромео і Джульєтта».

На різних сценах він випустив шість опереткових спектаклів, працював із В. Маяковським над планом циркової пантоміми «Москва горить». У 1942 році в П'ятигорську разом із трупою потрапив у полон. Під час відступу німців трупу забрали в Запоріжжя, потім - у Берлін. У Франції митці виступали 3 концертами перед репатріантами й лікувалися, бо вже встигли заробити відкриту форму туберкульозу. За пропозицією радянської місії в Парижі 22 лютого 1945 р. режисер із дружиною $з$ радістю повернулися до Москви, одразу потрапивши до рук КДБ. Підставою одягти наручники на Радлових стали результати допиту «комітетчиками» Бориса Смирнова. Вирок було ухвалено 17 листопада 1945 р.: десять років ув'язнення за зраду Батьківщини. На захист Радлових одразу стали авторитетні артисти: М. Черкасов, Б. Бабочкін. Як результат, митців відправили під Рибінськ, у «Волголаг», у табір «з більш м’яким режимом».

Трупа Центрального театрального ансамблю КВО Волгобуду майже вся складалася $з$ професійних акторів, які здебільшого грали у визначних культурних центрах. Колектив близько двох років мав назву «Джаз». Першим порадником і єдиним фаховим поціновувачем праці С. Радлова в теа- тральному ансамблі була його дружина, визнана перекладачка п'єс Шекспіра, поетеса - Анна Дмитрівна Радлова. Адміністратором ансамблю був Левіт Борис Самійлович. У складі колективу були артисти драми (18 осіб у різний час), вокалісти (4 особи), оркестр (23 особи), музичні керівники оркестру (2 особи), художники (2 особи), балетмейстер (1 особа), завідувач постановочною частиною (1 особа), машиніст сцени (1 особа), інспектор сцени (1 особа), освітлювач та шумове оформлення (2 особи), костюмер (1 особа), консультант із костюмів (1 особа). Слід додати, що в структурі театрального ансамблю, крім М. Трегубова, були інші артисти балету з непростою долею: Тося Анджан, Марина Градовська, Н. Дементьєв, Михайло Дудко, Андрій Клименко, Марина Марченко, Лілія Сфаело.

Ансамбль мав своє приміщення, класи, де проводилися репетиції та костюмерні. У керівника колективу, тобто в С. Радлова, був свій службовий кабінет.

Опрацьований режисером репертуар табірного ансамблю складався з класичних і сучасних драматургічних творів, які не потрапили до списку заборонених, та концертних програм, що їх готували спеціально до державних свят СРСР (1 i 9 травня, 23 лютого, 8 Березня, жовтневі свята, Новий рік). Концертна програма складалася $322-x$ номерів вітально-мажорного характеру з використанням тексту, музики, танцювального і вокального мистецтва. Тут знаходимо і веселі водевілі («Аз і Ферт» П. Федорова), адаптований балет («Бахчисарайський фонтан» Б. Асафьєва), тематичні концерти за творами О. Пушкіна і В. Шекспіра. Репертуар ансамблю характеризувався різноплановим розмаїттям та масштабністю.

Артисти все здобували й робили виключно своїми силами. Самотужки дбали про декорації, монтування, костюми, перуки, бутафорію, світло, музику - від задуму до втілення - за мізерних, майже нульових технічних можливостей. Наприклад, костюми для чоловіків шили у буквальному сенсі з липової матерії, не стільки голкою, скільки своєю безмежною вигадкою, а для жінок - з марлі, котру фарбували в різні кольори. Бутафорію клеїли з картону і власноруч розфарбовували.

Труднощів додавало й те, що кожну нову роботу колективу оцінювала приймальна комісія й Політвідділ табору. Тож адміністрування та постановки мали виконуватися на найвищому рівні. Але творчі виклики й організаційна тяганина не завадили гострому розуму, креативності С. Радлова створити зразковий табірний театр 3 
власним концертним розкладом та графіком гастролей.

Аналіз репертуару ансамблю, листів подружжя Радлових і світлин, зібраних у книзі В. Гайдабури, дає можливість виокремити особистий внесок М. Трегубова в загальному творчому доробку табірного осередку мистецтва.

В ансамблі М. Трегубов був танцівником, балетмейстером, завідуючим постановочною частиною, а також виступав як драматичний артист. Так, аналізуючи програмку першої вистави табірного театрального ансамблю «Без вини винні» О. Островського, яка відбулася 11 квітня 1946 р., знаходимо М. Трегубова у якості постановника танців і виконавця ролі Миловзорова (першого коханця провінційної актриси Карінкіної).

Як відбувалася підготовка до вистави, дізнаємося $з$ листа А. Радлової за 28 лютого 1946 р.: «Сергій ставить „Без вини винні”, ролі вже розподілено, й увесь наш театр збуджений, як найсправжнісінький театр, актори сваряться через ролі й навіть поплакали, отримаши не ті ролі, на які розраховували, хвилюються й інтригують, як усюди» [6, 159]. Вистава мала великий успіх у глядачів. «За акторським складом і, головне, за зацікавленням роботою, - писала до С. Лебедєвої А. Радлова, - вона краща за „Без вини винних”, які йшли в нас у театрі в Ленінграді» [6, 162]. Прем'єра вистави пройшла блискуче, а станом на 20 квітня 1946 р. виставу вже двічі показували у Вільному клубі Переборів й у Рибінську, де їі дивилася вільна публіка.

3 огляду на табірні розпорядки, режисерові 3 дружиною досить часто доводилося долучати до драматичних ролей танцівників, танцівниць i співачок, про що неодноразово читаємо в їхній епістолярній спадщині. Так, впізнаємо М. Трегубова-актора на світлині, де зображені учасники вистави «Фатальний спадок» О. Штейна. Він сидить у першому ряду ліворуч від режисера. 3 огляду на те, що М. Трегубов у минулому відзначився балетними партіями, які передбачали експресивність характеру й образу, можна припустити, що зі своїми акторськими обов'язками він впорався якнайкраще.

Віднайдено балетмейстерські роботи М. Трегубова й у пушкінському «Борисі Годунові». У сцені на балу в замку Мнішека хореограф поставив «полонез», де танцюють і розмовляють чотири пари і відбувається діалог старого Мнішека 3 Вишневецьким. Загалом концерт мав великий резонанс і найсприятливіші організаційні висновки: після вистави всьому ансамблю покращили хар- чування, а постановники (у тому числі й А. Радлова) отримали преміі.

У листі А. Радлової за 23 березня 1946 р. знаходимо інформацію про репетицію «чарівного балету» до свята 1 травня. Авторка повідомляє, що в ньому танцюватимуть «двоє чудових ленінградських танцівників і одна московська молода танцівниця» $[6,163]$. Ймовірно, йдеться про одноактний комічний балет «Арлекін-рознощик» на музику вальсів, польок, маршів Й.Штрауса, а виконавцями були М. Трегубов і М.Дудко обидва навчалися, працювали в Ленінграді. Також до концертної програми увійшли циганський номер, який супроводжувався табірними піснями, танками й пантомімою, окремі танцювальні, співочі, розмовні номери й одна одноактна п'єса. Як балетмейстер М. Трегубов міг здійснити хореографічну частину концерту.

У репертуарі ансамблю знаходимо ще одну композицію балету «Бахчисарайський фонтан» Б Асафьєва. Можемо припустити, що й цією постановкою міг займатися М. Трегубов, адже ще в Ленінграді, у часи свого навчання й роботи, він дивився «Бахчисарайський фонтан» у втіленні р. Захарова. У 1938 році артист сам почергово танцював партії Гірея і Вацлава на сцені Київського академічного театру опери і балету, а його колега М. Дудко вважався найкращим виконавцем вищезгаданої партії в Ленінградському театрі опери і балету.

Умови праці й режим роботи ансамблю були виснажливими, про що дізнаємося зі звіту адміністратора ансамблю Б. Левіта під назвою «Творче піднесення». Замітка була надрукована у «Виробничому бюлетені» №8 за 14 серпня 1947 р. (видання Політичного відділу, яке не можна було виносити за межі табору). Вона дає уявлення про обсяг роботи і високу відповідальність артистів. Газетна шпальта, на якій було надруковано замітку, вийшла під рубрикою «Продуктивно працювати, культурно відпочивати!» $[6,44]$.

«За минулі три місяці Центральний театральний ансамбль КВО дав сімдесят сім виступів, відвідавши всі підрозділи табору. До цих гастрольних поїздок ансамбль підготував три великі концертні програми і два спектаклі. Виступи відбувалися i вдень, і ввечорі, щоб було обслужено не лише працівників денної, але й нічної зміни. Спеціальні програми показано в стаціонарах для хворих і в оздоровчих пунктах.

Усюди глядачі тепло зустрічали наші виступи. Це стало результатом великої творчої праці, прагнення майстерно виконати кожний номер 
у концерті, створити яскраві, правдиві образи в спектаклях, які запам'ятовувався надовго. Найбільший успіх заслужили В.Г. Яковлєв, В. Н. Стальський, В. С. Кобяк, М. І. Трегубов, М. П. Градовська» $[6,44]$.

У процесі дослідження звіту доводиться переконатися, що праця артистів свідомо була організована начальством для виснаження нервів i фізичних сил. Тому не дивно, що цей вид діяльності порівнювався 3 лісоповалом. До заслуг М. Трегубова, безперечно, слід додати й те, що він переживав ці табірні поневіряння досить непогано: давалося взнаки міцне здоров'я, яке не змогла підірвати важка творча праця. Йому вдавалося зберігати достатню енергійність, нестримну жагу до життя і впродовж наступних років, про що неодноразово згадували його колеги та учні.

Артисти ж із слабким здоров'ям помирали від фізичного і психологічного напруження. Так, одразу після вистави «Коли розсіюється туман» Л.Карасьова помер артист М.Островський (у нього було хворе серце), від крововиливу в мозок раптово загинула провідна актриса Л. Василенко, яка грала Донну Анну з «Камінного гостя» й Катерину 3 «Приборкання норовливої». Через три роки ув'язнення, тобто 23 лютого 1949 р., від хвороби серця померла і дружина С. Радлова - Анна.

Не додавав митцям сил і суворий клімат краю. Потужні вітри, а взимку люті морози до 35 градусів, тривали навіть до травня, сніг із хуртовинами - до березня. Часто через несприятливі погодні умови і відсутність транспорту посилки, що їх з нетерпінням чекали в'язні, затримувалися на пошті. Побут артистів ансамблю за колючим дротом також не відрізнявся особливим комфортом. Вони жили в бараках, де постійно заводилися миші й щури.

М. Трегубов як учасник колективу отримував свою «звичайну зарплату» - 100 карбованців, іноді - премії в розмірі місячної зарплати й подяки, які заносилися в особову справу. Щомісячну преміальну нагороду, скромну, але диференційовану за кваліфікацією, отримували ті артисти, які виконували план табірного керівництва. Хоча це були невеликі кошти, їхня цінність i, насамперед, практичне значення були принциповими. Також артисти мали особовий рахунок, на який можна було переказувати гроші.

Останніх, до речі, катастрофічно не вистачало. Лише фінансова підтримка рідних допомагала в’язням протриматися до наступного місяця. На ці кошти в лазаретній крамниці, яка була набагато кращою за звичайну, можна було придбати масло (кілограм - 170 крб.), яйця (десяток - 35 крб.), часто яблука (кілограм - 40 крб.), цукор (кіло 75 крб.), можливо було навіть дістати туалетне мило вартістю від 45 до 300 крб. за невеликий шматок $[6,156]$.

Що ж до продовольчого забезпечення, то артистам видавали сухий пайок на місяць. Очевидно й те, що цього набору не вистачало на визначений час, тож усі інші господарські справи члени колективу вирішували самотужки, хто як міг. Діставали молоко й картоплю, траплялося, що мали цибулю та часник, а іноді - свіжу рибу. Такі делікатеси, як кава, какао, лимони, і дрібниці - голки й нитки, шнурки для черевиків, персидський порошок від блощиць і свічки - замовляли рідним. Дарма говорити про фрукти - їх дістати було неможливо.

Для повноцінного функціонування ансамблю артисти, особливо керівник, 3 нетерпінням чекали з волі необхідну літературу. Ті, хто не боявся спілкуватися з в'язнями, допомагали друзям і пересилали необхідні матеріали: п'єси радянських і сучасних авторів, скетчі, естраду, нотний матеріал. На жаль, траплялося й так, що посилки не доходили до замовника й цінні книжки зникали без сліду.

Ансамбль багато гастролював. Їздив із концертами по Рибінському району й далі до Углича, Пошехонів, Рибінська. Виступав перед простими громадянами в державних театрах. Гастролі тривали від 3 тижнів до 1.5 місяця. Усюди артистів зустрічали 3 радістю: концерти і водевілі мали шалений успіх. А головне - артисти отримували внутрішнє задоволення від усвідомлення, що робили гідну справу, вони якнайкраще знайомили оточення $з$ мистецтвом.

Плинність кадрів і скорочення штату в колективі неймовірно засмучували керівника і всю трупу. Одні артисти звільнялися або виїжджали на вільне поселення, інших треба було заново навчати театральних премудростей.

3 листа режисера С. Радлова від 1 січня 1950 р. дізнаємося, наскільки майстер цінував М. Трегубова: «Справа в тому, що ми дуже незадовго до нового року повернулися на місце після гастрольної поїздки, і почалася природна метушня $з$ монтуванням, пошиттям костюмів і т. д. А тут ще звільнився мій незвичайно енергійний завідувач постановочною частиною (одночасно гарний танцівник і балетмейстер)» $[6,102] .3$ цього тексту стає відомо, що М. Трегубова було звільнено після чотирьох років принизливих умов і примусової праці. Сталося це наприкінці 1949 р. 
У приватній розмові заслужений артист УРСР, професор Олександр Петрович Колосок, який багато років працював з М. Трегубовим на кафедрі народної хореографії Київського державного інституту культури ім. О. Є. Корнійчука, розповідав, що за його колегу клопотав «впливовий поляк», шанувальник його творчості. Можливо, це вплинуло на дострокове (майже на рік) звільнення артиста 3 табору. Через кілька місяців М. Трегубов повернувся до Львівського державного театру опери та балету й розпочав нове життя.

Отже, завдяки архівним, епістолярним джерелам та останнім науковим розробкам, вдалося відтворити передумови ув'язнення заслуженого артиста УРСР М. Трегубова, особливості його життя і творчості за часів перебування в таборі системи ГУЛАГ - величезної кривавої плями в історії радянського тоталітарного режиму.

Попри те, що віднайдені документи повертають в історичний обіг викреслені сторінки біографії митця, подальших наукових пошуків потребують обставини арешту та причини дострокового звільнення М. Трегубова, питання його реабілітації.

1. Серед вихованців балетного цеху, які потрапили до ансамблю С. Радлова, слід виділити Михайла Андрійовича Дудка (1902-1981) - заслуженого артиста РРФСР (1939), з яким М. Трегубов міг спілкуватися ще в Ленінграді, коли навчався в хореографічному технікумі, а пізніше - у період 1935-1937 рр., коли танцював у Кіровському театрі.

2. М. Дудко закінчив ПХУ в 1920 році. Навчався у С. Андріанова, В. Семенова та Л. Леонтьєва. Після закінчення училища був прийнятий на посаду соліста Петроградського театру опери і балету (пізніше Ленінградський театр імені С. М. Кірова), де танцював до 1941 р. Він був першим виконавцем партій Ганса («Сольвейг»), Соліст («Шубертіана»), Капітан («Партизанські дні»), Командор («Лауренсія»), Тарас («Тарас Бульба»). Був партнером Є. П. Гердт, пізніше Г. С. Уланової, Н. М. Дудинської. Артист тривалий час був одним із перших танцівників ленінградського балету і вважався яскравим представником «французької школи». Під час війни потрапив в окупацію і виступав у концертній бригаді разом зі співаком Миколою Печковським. Після війни М.Дудко був репресований і відправлений до табору. У 1953-1962 pp. працював у театрах опери і балету Уфи, Новосибірська, Тбілісі.

3. Партнеркою М. Дудка, який ще до початку війни вважався найкращим виконавцем партії Гірея, була танцівниця Марина Градовська. Ї̈̈ кинули до табору, пригадавши, що під час німецької окупації вона працювала в театрі, де надто темпераментно танцювала «Яблучко». В ансамблі Марина виконувала, зокрема, партію Зареми в адаптованій композиції балету «Бахчисарайський фонтан» Б. Асаф'єва.

\section{Джерела та література}

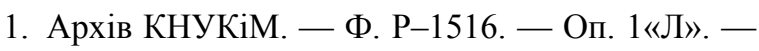
Спр. 195. - 21 арк.

2. Барвінський В.Прем'єра опери-хвилинки М. Лисенка «Ноктюрн» / В. Барвінський // Львівські вісті. - 1944. - 14-15 травня.

3. Вистава балету «Дон Кіхот»// Львівські вісті. - 1944. - 28 квітня.

4. Відвідини у Терпсихори. На пробі балету Львівського Оперного театру // Львівські вісті. - 1944. 4-5 червня.

5. В. С. «Пташник з Тиролю» (3 театральної зали) / С. В. // Краківські вісті. - 1943. - 8 травня.

6. Гайдабура В. ГУЛАГ і світло театру : Листи із зони Сергія та Анни Радлових (1946-1953) / Валерій Михайлович Гайдабура. - Київ : Факт, 2009. $240 \mathrm{c}$.

7. Гайдабура В. Театр між Гітлером і Сталіним : Україна ; 1941-1944. Долі митців / Валерій Михайлович Гайдабура. - Київ : Факт, 2004. - 320 с.

8. 27.730 зл. від Львівського Оперного театру для раненого вояка на різдвяний дарунок // Львівські вісті. - 1943. - 5 грудня.

9. Епплбом Е. Історія ГУЛАГу / Пер. 3 англ. А. Іщенка. - 2-ге вид. - К. : Вид. дім «Києво-Могилянська академія», 2010. - 511 с.

10. 3 театру. Сорокатий вечір у Львівському театрі // Львівські вісті. - 1944. - 16-17 січня.

11. Івасівка М. Український оперний театр у Львові // Наш театр. Книга Діячів Українського Театрального Мистецтва. Т. 1. - Нью-Йорк - Париж - Сідней - Торонто, 1975. - 847 с.

12. Інформація про результати діяльності Львівського академічного театру опери та балету імені Соломії Крушельницької за 2015 рік [Електронний ресурс]. - Режим доступу: http://opera.lviv.ua/wp-content/ uploads/2015/12/INFORMATSIYA_rik_SAJT_.pdf.

13. Максименко С. Театральне життя Львова 1941-1944 pp. / С. Максименко // Науковий вісник Киїського національного університету театру, кіно і телебачення імені I. К. Карпенка-Карого. — 2013. - Вип. 13. - C. 67-84.

14. Максименко С. Український театр у Львові в період німецької окупації (1941-1944) / С. Максименко. - Львів, 2015. - 328 с.

15. Миронюк Н. Балетмейстерська діяльність Миколи Трегубова у Львові під час фашистської окупації 1941-1944 рр. / Н. Миронюк // Хореографія ХХІ століття: мистецький та освітній потенціал : зб. матеріалів Всеукр. наук.-практич. конф. - Київ : КНУКІМ, 2016. - С. 131-132.

16. Миронюк Н. Діяльність М. Трегубова у воєнні роки та їі наслідки / Н. Миронюк // Тенденції розвитку хореографічних дисциплін у вищих мистецьких навчальних закладах : зб. матеріалів Всеукр. наук.-практич. конф. - Київ : КНУКІМ, 2014. - С. 83-85.

17. Народна артистка СРСР Лідія Чернишова : 3б. / Редкол. : Станішевський Ю. О. (голова) та інші. Київ : Мистецтво, 1978. - 176 с.

18. Оголошення // Краківські вісті. - 1943. - 22 жовтня.

19. Оголошення // Наші дні. - 1944. - січень. 
20. Паламарчук О. А музи не мовчали / О. Паламарчук. - Львів : Зерна, 1996. - 96 с.

21. Пастернакова М. 3 театру / М. Пастернакова // Краківські вісті. - 1943. - 17 жовтня.

22. По родной земле. 3500 километров с Красной Армией // Советское искусство. - 1945. 1 января.

23. Продана наречена // Краківські вісті. 1943. - 7 листопада.

24. Семчишин М. На службі в Мельпомени (Два роки праці Оперного Театру у Львові) // Наші дні. 1943, серпень.

25. «Серпанок П'єретти». Прем'єра балету у Львівському оперному театрі // Львівські вісті. 1943. - 10 жовтня.
26. 750 вистав Українського театру у Львові // Краківські вісті. - 1944. - 1 січня.

27. Суриц Е. Я. Все о балете : словарь-справочник / Е. Я. Суриц. - Ленинград : Музыка, 1966. - 454 с.

28. Сьогодні зустріч з артистами Львівського Оперного театру // Львівські вісті. - 1943. - 30 листопада.

29. Трегубов Николай Иванович [Электронный ресурс] // Списки жертв. Мемориал. - Режим доступа : http://lists.memo/ru/d32/f460.htm.

30. Туркевич В. Хореографічне мистецтво у персоналіях : [біобібліографічний довідник] / В. Д. Туркевич. - Київ, 1999. - 224 с.

31. Хоминський Й. Прем'єра «Маргарети» («Фавста») Гуно в Оперному Театрі / Й. Хоминський // Львівські вісті. - 1944. - 17 лютого. 